City University of New York (CUNY)

CUNY Academic Works

2020

\title{
THE IMPORTANCE OF UNDERGRADUATES EXPOSURE TO THE GEOSCIENCES INDUSTRY: PRELIMINARY CASE STUDY-BASED OUTCOME AT CUNY - YORK COLLEGE
}

Malek Shami

cUNY York College

Nazrul I. Khandaker

cUNY York College

Ruslana Baker

Arizona State University

Gurwinder Sahota

cUNY York College

Toralv B. Munro

CUNY York College

See next page for additional authors

\section{How does access to this work benefit you? Let us know!}

More information about this work at: https://academicworks.cuny.edu/yc_pubs/294

Discover additional works at: https://academicworks.cuny.edu

This work is made publicly available by the City University of New York (CUNY).

Contact: AcademicWorks@cuny.edu 


\section{Authors}

Malek Shami, Nazrul I. Khandaker, Ruslana Baker, Gurwinder Sahota, Toralv B. Munro, and Stanley Schleifer 
THE IMPORTANCE OF UNDERGRADUATES EXPOSURE TO THE GEOSCIENCES INDUSTRY: PRELIMINARY CASE STUDY-BASED OUTCOME AT CUNY - YORK COLLEGE

SHAMI, Malek ${ }^{1}$, KHANDAKER, Nazrul I.2, BAKER, Ruslana,

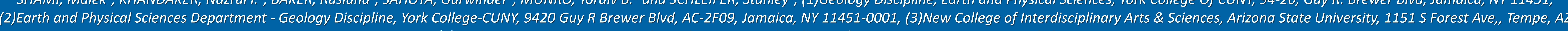

Traditionally, a limited percentage of undergraduate geology students have the opportunity to explore the geology profession in private, nonprivate industry, city and federal agencies, while a relatively larger number of graduating students pursue higher education to ultimately find a career in academia, city and federal agencies. For the past three semesters, a pilot study that provided more exposure to the geology profession was conducted at the Earth and Physical Sciences Department of the City University of New York. This adaptive teaching approach designated $20 \%$ of each upper level geology gateway courses (Structural, Mineralogy, Petrology, Soil Mechanics, and Sedimentation) to the analysis and evaluation of active geological and geotechnical project in New York City (NYC) and adjoining areas. Particularly, the NYC Department of Environmental Protection (NYCDEP)-supported active Green Infrastructure Project became the base of students learning skills concerning project management and assessment aspects. Lectures and online discussions included the project's cost analysis, participating stakeholders' priorities, community involvement, feasibility evaluation, scheduled timeline with deliverables, and intended outcomes. Utilizing public information obtained primarily from open access online sources, students explored the benefit of the NYCDEP Green Infrastructure Initiative with emphasis on the successful implementation of integrated water management of urban systems focusing on synergies between drinking water, wastewater, and stormwater management. The product of this teaching approach yielded two unique results. First, more students took interest in seeking a career in field or exploration geology as opposed to academia; secondly, others narrowed the target of their higher education goal to integrate field geology with urban sustainability to achieve maximum effectiveness. Based on a recent GeoSummit (2019), hosted by the Jackson School of Geosciences, University of Texas at Austin, it became quite apparent that many geoscience practioners felt th urgent need to allow students to acquire some training and learning skills involving business management with basic accounting knowledge. Man potential geoscience employers are encouraging students to be familiar with soft skills (social), basic accounting, and training in faculty-led summer research or internships. 85281, (4)Geology Discipline, Earth and Physical Sciences, York College Of CUNY, 94-20 Guy R. Brewer Blvd, Jamaica, NY 11451

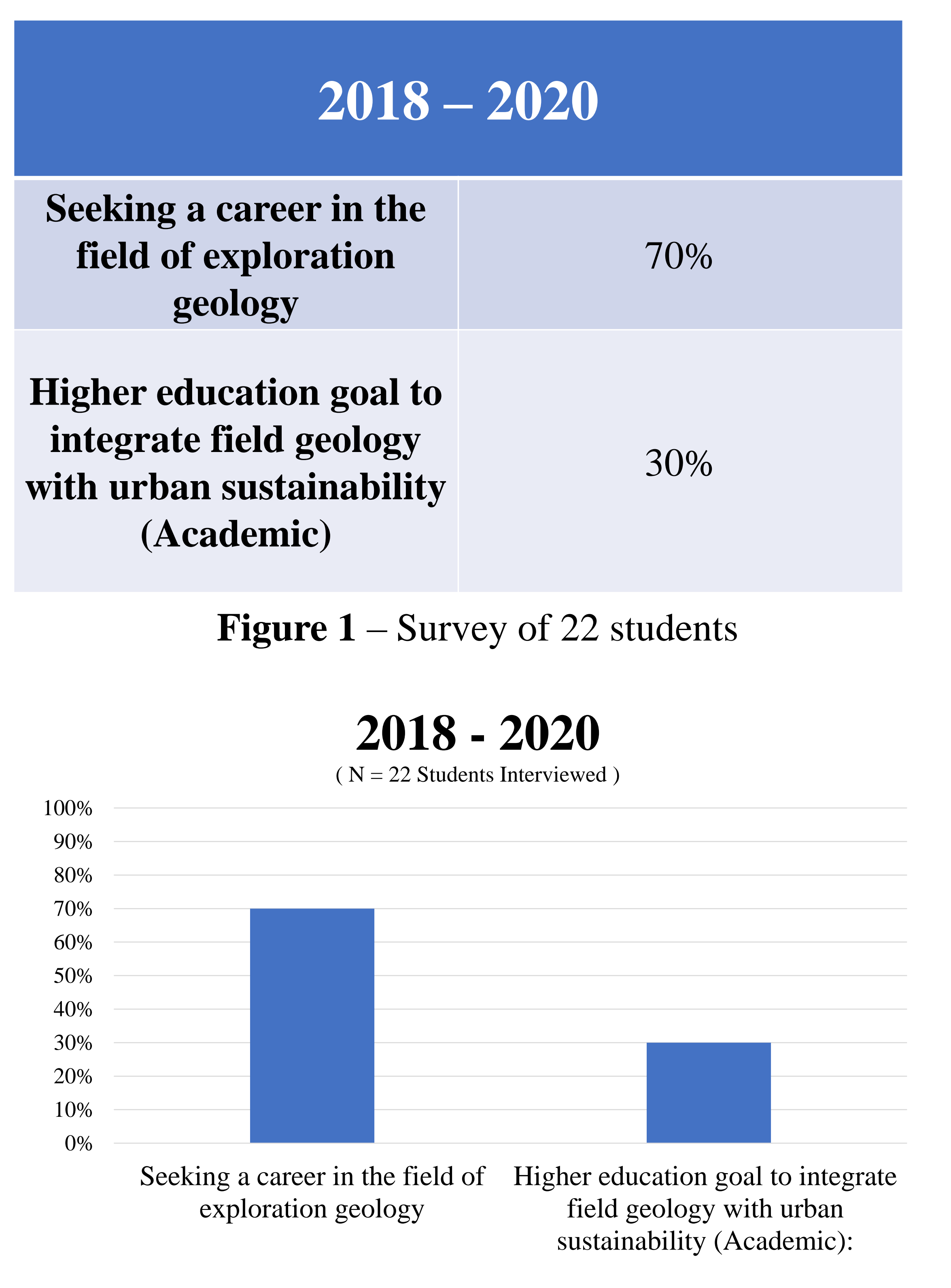

Figure 2- Career Choice Responses (data from Figure 1) Survey Highlights

Data from 2003-2017 and 2017-2020 suggest a declining interest level to become geoscience educator and an increased desire to pursue field and exploration-based career. Financially disadvantaged and being minorities, our students consider academic track as a long-term process and deem it to be highly competitive. Recent focus on infrastructure development and maintenance of aging infrastructure, urban geology, pollution control and climate-induced adverse phenomena are becoming the focal points for recent geology students to consider field-based track and seek future employments (Figure 1 through 3).

Acknowledgements: Support from the York College, survey participants, and summer research students made this happen. Financial support came from AT\&T and Con Edison. Authors greatly acknowledge everyone who participated in this preliminary career-choice -related research investigation.
This space will be atomatically filled with a QR code and number for easy sharing

\begin{tabular}{|c|c|c|}
\hline \multicolumn{3}{|c|}{$2003-2017$} \\
\hline \multirow{4}{*}{$\begin{array}{l}\text { Field of } \\
\text { Exploratic } \\
\text { n Geology }\end{array}$} & City Agency & $4 \%$ \\
\hline & $\begin{array}{l}\text { Environmental/Engineering } \\
\text { Firms } \\
\text { Exploration }\end{array}$ & $11 \%$ \\
\hline & Geology (Oil and Gas) & $4 \%$ \\
\hline & Federal Government (EPA) & $4 \%$ \\
\hline \multirow{4}{*}{$\begin{array}{l}\text { Higher } \\
\text { Education } \\
\text { \& Non- } \\
\text { Geology } \\
\text { (sub } \\
\text { categories) }\end{array}$} & $\begin{array}{l}\text { Graduate School (MS or } \\
\text { equivalent, completed or in } \\
\text { progress) } \\
\text { *Includes } 8 \text { students } \\
\text { Completed MS and now in } \\
\text { teaching profession }\end{array}$ & $31 \%$ \\
\hline & Military/National Guard & $4 \%$ \\
\hline & $\begin{array}{l}\text { Non Geology (Business, IT, } \\
\text { Public Health, Gem } \\
\text { inspector) }\end{array}$ & $15 \%$ \\
\hline & $\begin{array}{l}\text { Teaching (Adjunct, K9-12 } \\
\text { and Substitute Teacher) }\end{array}$ & $26 \%$ \\
\hline
\end{tabular}

Figure 3 - Survey of 73 former students

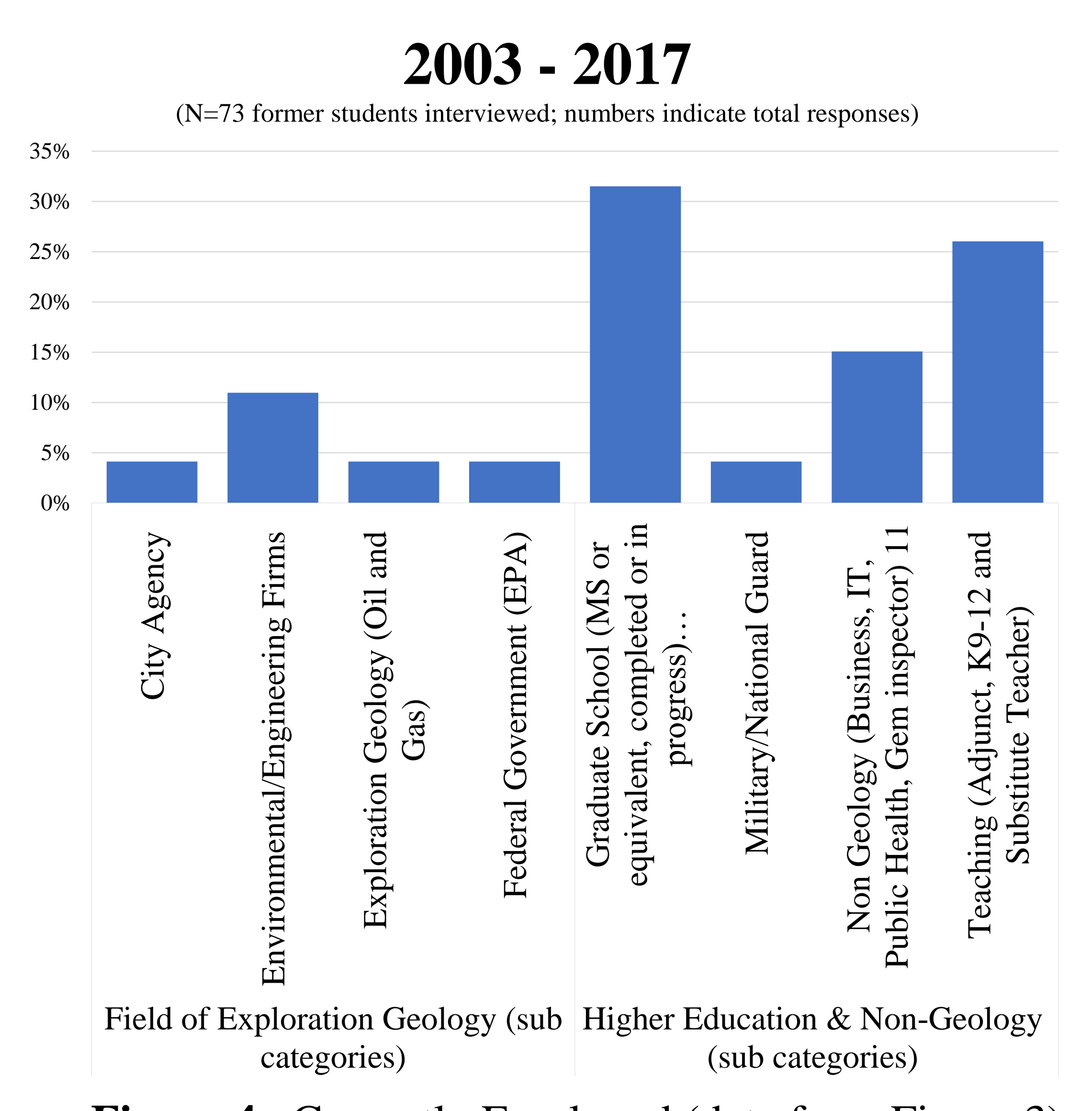

Figure 4- Currently Employed (data from Figure 3)
References

Green Infrastructure. New York City Department of Environmental Protection. Accessed on October 4, 2020. Available online

at: https://www1.nyc.gov/site/dep/water/greeninfrastructure.page

Universal Skills for Geoscience Graduate Student Success in the Workforce.

AGU/AGI Heads and Chairs Webinar: Sharon Mosher, University of Texas at Austin \& Jeff Ryan, University of South Florida. 2019

Available online

at: https://www.jsg.utexas.edu/events/files/Grad_skills_E mployers Academics.pdf

Will be covered by controls

if you define slides 